University of Nebraska - Lincoln

DigitalCommons@University of Nebraska - Lincoln

Faculty Publications, College of Journalism \& Journalism and Mass Communications, College Mass Communications

9-25-1985

\title{
Agreement Between Reporters and Editors in Mississippi
}

Will Norton Jr.

University of Nebraska-Lincoln, hwnorton@gmail.com

John W. Windhauser

Louisiana State University

Allyn Boone

Mississippi Magazine

Follow this and additional works at: https://digitalcommons.unl.edu/journalismfacpub

Part of the Journalism Studies Commons

Norton, Will Jr.; Windhauser, John W.; and Boone, Allyn, "Agreement Between Reporters and Editors in Mississippi" (1985). Faculty Publications, College of Journalism \& Mass Communications. 10.

https://digitalcommons.unl.edu/journalismfacpub/10

This Article is brought to you for free and open access by the Journalism and Mass Communications, College of at DigitalCommons@University of Nebraska - Lincoln. It has been accepted for inclusion in Faculty Publications, College of Journalism \& Mass Communications by an authorized administrator of DigitalCommons@University of Nebraska Lincoln. 
Other studies suggested that a high degree of similarity occurred in the news selection process among television and newspaper editors, ${ }^{6}$ and among journalism instructors and their students. ${ }^{7}$ Photographers and editors, ${ }^{8}$ along with photojournalism teachers, ${ }^{9}$ also were quite alike in their selection of news photographs.

While these various gatekeeping studies attempted to describe the aspects of news selection process, not one study focused on the homogeneity of the news process, or the lack of it, among editors and reporters within a state. We wanted to find out in what types of news situations reporters and editors differ.

\section{Agreement Between Reporters And Editors in Mississippi}

\author{
By Will Norton, Jr., John W. \\ Windhauser, and Allyn Boone
}

- Both newspaper editors and reporters act as decision makers in their selections of "newsworthy" events to be published. But what editors include in newspapers is influenced by the news values of their colleagues or superiors.'

Studies of gatekeepers who control the flow of news have reported such results about the news selection process. Individual opinions of editors, ${ }^{2}$ newsroom schedules and publication technicalities, ${ }^{3}$ and news sources ${ }^{4}$ were found to affect choices of stories. Similarly, selected social and structural characteristics of media organizations had "subjective" implications for media "output."

\footnotetext{
- ' Gaye Tuchman, "Objectivity as Strategic Ritual: An Examination of Newsmen's Notions of Objectivity," American Journal of Sociology. 77:660-79 (January 1972); David R. Bowers,
}

(Fovimole coninued)

\section{Method}

Our sample was limited to 240 Mississippi journalists, with 101 editors and 139 reporters. ${ }^{10}$ The response rate was $63 \%$. To look at the differences in handling news situations, we developed 17 hypothetical news situations that working journalists might face.

Nine of the cases were based on complaints reported by the National News Council. The 17 news situations were pretested with 29 reporters and editors working at six different daily newspapers in Arkansas and Alabama. The nine news situations taken from the National News Council were:

Reliance on university news bureau as source of arrest information. Several people are arrested at a campus riot. The university news bureau releases the names and a reporter lists them in his story. Because of deadline pressure, the reporter does not verify the names with police. (Evaluate the reporter's action.)

Manipulation of facts in a cartoon. A cartoonist wants to illustrate the economic factors behind the slaughter of baby Canadian seals. Although Canadian seals are not used for fur garments, the cartoonist implies in the cartoons that skins from baby Canadian seals will be made into fur

- Norton is chairman of the Department of Journalism at the University of Mississippi. Windhauser is a faculty member in the Manship School of Journalism at Louisiana State University and Boone is editor of Mississippi Magazine. 
coats. (Evaluate the cartoonist's action.)

Failure to run columnist's retraction. A paper carries a column accusing a foreign official of profiting from a disaster. One year later, the columnist issues a retraction. The editorial-page editor decides the matter is not relevent to the paper's readers and does not run the retraction. (Evaluate the editor's action.)

Subterfuge by a reporter. To get a story of Medicaid abuse, the reporter obtains a fraudulent Medicaid card and is examined by area doctors for a "sore throat." He writes a story detailing the treatments the doctors prescribe. (Evaluate the reporter's action.)

Use of names in an article. Same as above. but the doctors are named in the article. (Evaluate the reporter's action.)

Failure to disclose possible conflict of interest. A columnist writes several articles detailing union lobbying expenditures. The columnist is a member of an anti-union citizens' lobby, but the reporter does not note this fact in the columns. (Evaluate the columnist's action.)

Placement decision on "right to life" story. A "right to life" group holds a protest march. An editor decides readers are tired of such protests and runs the story deep inside the paper with no photo. (Evaluate the editor's action.)

Lack of balance in advocacy article. In an article on methadone maintenance programs, the writer contends that the programs have little effect on drug-related crime and that most patients continue to abuse other drugs. The reporter cites statistics to back up the claims. but does not quote anyone in favor of the program. (Evaluate the writer's action.)

Lack of balance in spot news article. A bill is introduced to restrict oil companies. The reporter covering Capitol Hill writes an article on the bill's introduction, quoting the bill's sponsor. The reporter does not contact oil company representatives, who oppose the bill. (Evaluate the reporter's action.)

\section{The other eight cases were:}

Firing of a reporter. A reporter makes an error that causes the paper embarrassment and legal concern. It is the reporter's third mistake in six months. The editor fires the reporter. (Evaluate the editor's action.)

Publication of accusations. At a press conference, one city official accuses another of misconduct. The reporter covering the story doesn't have time before the deadline to check the accusations or reach the accused for comments. The reporter writes an article listing the accusations and saying the official could not be reached for comment. (Evaluate the reporter's action.)

Decision to run wreck story on Page 1 instead of "Teacher of the Year" story. A gruesome local car-train accident occurs at 10 p.m. and the news editor remakes Page 1 to run the story and a photo. To make room, the editor moves a feature on a local

-A Report on Activity by Publishers in Directing Newsroom Decisions," Journalism Quarlerly 44:43-52 (Spring 1967); Walter Ward, "News Values, News Situations, and News Selection: An Intensive Study of Ten City Editors," unpublished Ph.D. dissertation, University of lowa (1967).

2 Gary Norman Van Tubergen, "Racial Attitudes of Gatekeepers." unpublished Ph.D. dissertation. University of lowa (1968): Ward, op. cit.: Ward, et. al., The Noture of Nen's in Three Dimensions, Stillwater, Okla.: Monograph published by Oklahoma State University Burcau of Media Research (1973); David Manning White, "The Gatekeeper: A Case Study on the Selection of News," Journalism Quarterly. 27:383-90 (Fall 1950): Paul B. Snider, "Mr. Gates Revisited: A 1966 Version of the 1949 Case Study," Journalism Quarıerly, 44:419-27 (Autumn 1967).

3 Walter Gieber. "News is What Newspapermen Make It." in Lewis A. Dexter and David M. White, eds., People, Society. and Mass Communication (Glencoe, I11.: The Free Press. 1964); Robert Jones, ef al., "News Selection Patterns from a State TTS-Wire," Journalism Quarter/y, 38:303-12 (Summer 1961); Barry Liebes, "Decision Making by Telegraph Editors." Journalism Quarierly, 43:434-42 (Autumn 1966): "How Newspapers Use The Associated Press Afternoon A-Wire," Journalism Quarterly. 41:380-84 (Summer 1964).

4 Gieber. "Two Communicators of the News: A Study of the Roles of Reporters and Sources," Social Forces, 39:76-85 (October 1960); Gieber and Walter Johnson, "The City Hall Beat: A Study of Reporter and Source Roles." Journalism Quarterly, 38:289-97 (Summer 1961); Robert P. Judd, "The Newspaper Reporter in a Suburban City." Journalism Quarrerly, 38:35-42 (Winter 1961).

S Albert D. Talbott. "Some Implications of Selected Social Structural Characteristics of the Media Organization to "Output of the Media," an unpublished paper. Department of Communication, Michigan State University (1965).

- Robert W. Clyde and James K. Buckalew. "Inter-Media Standardization: A Q-Analvsis of News Editors," Journalism Qwarterly, 46:349-5I (Summer 1969); David Gold and Jerry L. Simmons, "News Selection Patterns Among lowa Dailies," Public Opinion Quarrerly, 29:425-36 (Fall 1965).

7 L. Erwin Atwood and Gerald L. Grotta, "Socialization of News Values in Beginning Reporters," Journalism Quarterly. 50:759-61 (Winter 1973).

- Walter Wilcox, "The Staged News Photograph and Professional Ethics," Journalism Quarterly. 38:497-504 (Autumn 1961).

- Fred Parrish. “More Than Meets the Eye," College Press Review, 14:23-27 (Summer 1975).

10 The sample was compiled by calling the editor or managing editor of the 25 daily newspapers in the state. and by asking for the names of the other major editors (news. city, or editor-inchief). and the reporters on his or her news staff. Editors and reporters in sports, women's, and other specialized areas were not included in this study. 
TABLE 1

Evaluations of News Situations by Reporters and Editors

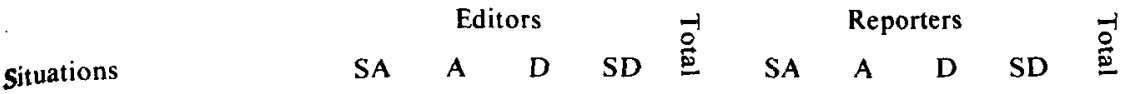

Reliance on university news

bureau as source of arrest

information .............

$\begin{array}{llllllllll}2.9 & 27.5 & 50.7 & 18.8 & (69) & 5.1 & 26.6 & 46.8 & 21.5 & (79)\end{array}$

Manipulation of facts in a

cartoon Failure to run columnist's

$\begin{array}{lllllllllll}\text { retraction } \ldots \ldots \ldots \ldots \ldots \ldots & 28.8 & 59.1 & 12.1 & 0.0 & (67) & 21.8 & 66.7 & 11.5 & 0.0 & (78)\end{array}$

$\begin{array}{llllllllllll}\text { Subterfuge by a reporter } & \ldots & 2.9 & 5.8 & 44.9 & 46.4 & (69) & 6.3 & 5.0 & 43.8 & 45.0 & \text { (80) }\end{array}$

Use of names in an

$\begin{array}{llllllllllll}\text { article } \ldots \ldots \ldots \ldots \ldots \ldots \ldots & 9.0 & 64.2 & 22.4 & 4.5 & (67) & 7.6 & 67.1 & 17.7 & 7.6 & \text { (79) }\end{array}$

Failure to disclose possible

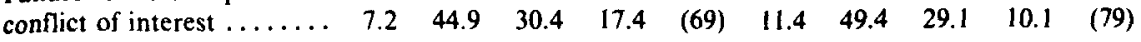

Placement decision on

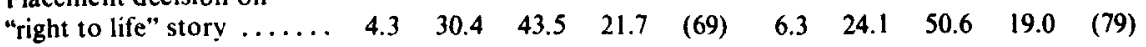

Lack of balance in

$\begin{array}{lllllllllll}\text { advocacy article } \ldots \ldots \ldots \ldots & 1.4 & 15.9 & 52.2 & 30.4 & (69) & 0.0 & 20.0 & 35.0 & 45.0 & \text { (80) }\end{array}$

Lack of balance in spot

$\begin{array}{lllllllllll}\text { news article } \ldots \ldots \ldots \ldots \ldots & 37.3 & 62.7 & 0.0 & 0.0 & (67) & 28.2 & 69.2 & 2.6 & 0.0 & \text { (78) }\end{array}$

$\begin{array}{lllllllllll}\text { Firing of a reporter } \ldots \ldots & 0.0 & 13.4 & 74.6 & 11.9 & (67) & 0.0 & 5.0 & 75.0 & 20.0 & \text { (80) }\end{array}$

Publication of

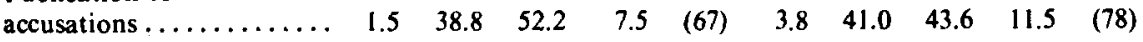

Decision to run wreck story

on Page 1 instead of

"Teacher of the Year"

story

$\begin{array}{lllllllll}23.9 & 59.7 & 14.9 & 1.5 & (67) & 32.1 & 53.8 & 12.8 & 1.3\end{array}$

Decision to publish

official's article on Op-Ed

page...................

$\begin{array}{llllllllll}7.4 & 54.4 & 33.8 & 4.4 & (68) & 13.9 & 46.8 & 32.9 & 6.3 & (79)\end{array}$

Decision to tell officials to

write a letter to the

editor.....

$\begin{array}{llllllllll}14.7 & 69.1 & 14.7 & 1.5 & (68) & 23.1 & 64.1 & 11.5 & 1.3 & (78)\end{array}$

Failure to respond to

complaint about wedding

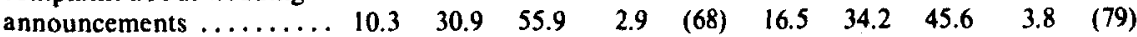

Failure to respond to

complaint about minority

$\begin{array}{llllllllllll}\text { coverage } \ldots \ldots \ldots \ldots \ldots \ldots & 5.9 & 7.4 & 70.6 & 16.2 & (68) & 3.8 & 8.9 & 57.0 & 30.4 & \text { (79) }\end{array}$

Hiring of black reporter

instead of a more

experienced white

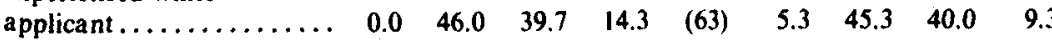

SA-Strongly Agree; A-Agree; D-Disagree; SD-Strongly Disagree 
person elected "State Teacher of the Year" to an inside page. (Evaluate the editor's action.)

Decision to publish official's article on Op-Ed page. A government official believes an article about him or her was misleading. The editor agrees to publish an article by the official on the "Op-Ed" page. (Evaluate the editor's action.)

Decision to tell official to write a letter to the editor. Same as above but the editor tells the official to write a letter to the editor. (Evaluate the editor's action.)

Failure to respond to complaint about wedding announcements. A group of women complain about the paper's new policy limiting wedding announcements. The editor does not re-evaluate the policy concerning weddings. (Evaluate the editor's action.)

Failure to respond to complaint about minority coverage. A group of blacks complain that blacks are portrayed only as criminals. The group requests increased coverage of the black community. The editor does not re-evaluate the paper's coverage of blacks. (Evaluate the editor's action.)

Hiring of black reporter instead of a more experienced white applicant. To increase minority employment on the staff, an editor hires a black reporter over a white reporter who has slightly more working experience. (Evaluate the editor's action.)

No names were included in the case examples and the respondents were given no clues concerning the authenticity of the cases. Each respondent was asked to evaluate the action taken in each news situation from strongly agree to strongly disagree.

\section{Results and Discussion}

Mississippi reporters and editors were quite alike in their responses for the 17 news situations, as shown in Table 1. More importantly, similar patterns existed regardless of the journalists' age, experience, college major, location of their newspaper in the state, or circulation of their newspaper. No significant differences. using the chi square test, were found.

The greatest agreement among the journalists was in response to the situation in which the editor decided to publish an article about a right-to-life march on an inside news page. Nearly every respondent agreed with the editor's decision. Other cases having a high agreement score included a situation in which the editor decided not to print a retraction to a columnist's article ( $90 \%$ disagreed); lack of balance in an advocacy article $(91 \%$ disagreed); and the editor's decision to fire a reporter who had made three serious errors ( $88 \%$ agreed).

In only four of the nine situations based on the National News Council cases did a majority of the state journalists agree with the council's decision. These included the editor's decision not to run a retraction, the reporter's action involving subterfuge, the editor's placement decision on the right-to-life story, and the columnist's failure to disclose a possible conflict of interest.

The greatest variations in responses were to cases that probed philosophical issues. Such cases included misrepresentation or subterfuge on the part of the reporters, response to complaints, and minority representation and coverage. Yet, those differences were not large enough or statistically significant to conclude that Mississippi journalists, regardless of their background, differed very much in handling news situations. Rather, the results indicated that Mississippi journalists were somewhat consistent. Results of this study suggest that a homogeneous pattern of news judgment may exist among journalists in a state on small-circulation dailies in scattered locations and provide additional evidence that such news selection agreement is not uncommon. 